\title{
Gaya Bahasa Luqman dalam Mendidik Anak (Uslub Mustawa an-Nahwi)
}

Chotibul Umam

Prodi Pendidikan Agama Islam

IAIN Pekalongan

Muhammad Alghiffary

Prodi Pendidikan Bahasa Arab

IAIN Pekalongan dhamaraksara@gmail.com

muhammad.alghiffary@iainpekalongan.ac.id

- Received: 28.03.2020 • Accepted: 27.04.2020 • Published online: 10.05 .2020

\begin{abstract}
This article aims to reveal Luqman's language style in educating his children. Language style is an alternative way of instilling knowledge in children. Oftentimes, the advice given by Stilistika is chosen as a tool because it can reveal Luqman's language style in educating children. Mustawa an-nahwi is the focus of stylistic studies because it is a minimal domain in conveying messages perfectly. The Luqman story was chosen because it became an ideal education icon according to the Qur'an. Through the descriptive method, the results of the discussion are as follows: Declarative style contains three meanings, namely: meaning that indicates weakness and solitude, meaning makes something big look small, verbs continuous and future also be interpreted in the past. The interrogative style has two meanings, namely: showing warning and amazement. The style of presenting and ending contains two meanings, namely: tasywì and ifädatu al-ikhtișās. Displacement style is communicated using three forms of displacement, namely: from damir huwa to nahnu, from fi'il mudhari to fi' il madhi, and from the jumlah of ismiyyah to the jumlah of fi'liyyah.
\end{abstract}

Keywords: stylistics, Luqman, mustawa An-nahwi, children's education

\section{Pendahuluan}

Pendidikan merupakan salah satu faktor penyempurna akhlak manusia. Sebab, dalam pendidikan manusia diberikan pengetahuan dan pemahaman dalam menjalankan kehidupan beragama dan bermasyarakat. Rasulullah bersabda, "inna ma bu'itstu li utammima makarima al-akhlak". Diutusnya Rasulullah kepada seluruh umat manusia tidak lain untuk 
menyempurnakan akhlak mereka. Meski secara resmi tugas tersebut hanya diemban Rasulullah, namun umat Muslim harus membantu melaksanakan misi utama Rasulullah. Paling tidak dalam kapasitasnya sebagai orang tua.

Dewasa ini, marak terjadi kasus kejahatan di lingkungan masyarakat. Hal ini diperburuk dengan pelaku kejahatan yang masih di bawah umur. Penganiayaan misalnya, banyak pula dilakukan oleh anak-anak yang masih memerlukan pengawasan orang tua. Menurut Prismatika, sebagaimana dikutip Hendarman, ada peningkatan kasus anak sebagai pelaku kejahatan dari tahun 2015 hingga 2017. Dalam kasus kekerasan fisik (penganiayaan, pengeroyokan, perkelahian, dan sebagainya) pada tahun 2015 tercatat 81 pelaku, 2016 tercatat 108 pelaku, dan 2017 tercatat 112 pelaku. Hendarman menjelaskan, ada beberapa faktor yang mendukung terjadinya kenakalan remaja. Salah satunya yaitu disfungsi keluarga. Orang tua memiliki peran penting dalam membentuk karakter anak. Oleh karenanya, orang tua harus bisa memahami karakter anak dan cara menyampaikan nasihat. Bahasa sebagai alat untuk menyampaikan nasihat memiliki andil dalam proses penangkapan dan pemahaman nasihat. Seringkali, nasihat kurang bisa diterima karena penggunaan bahasa yang kurang tepat (Hendarman, 2019).

Kisah Luqman yang diceritakan dalam al-Qur'an menjadi alternatif penyelesaian masalah dalam mendidik anak. Pilihan kata yang digunakan Luqman mampu mempengaruhi psikologis anaknya. Selain itu, Luqman juga berhasil merangkai kata menjadi kalimat yang indah. Ketepatan kata dan keindahan kalimat yang diungkapkan Luqman ditelusuri menggunakan teori stilistika atau dikenal pula dengan teori uslub. Uslub adalah cara berbicara yang diambil mutakallim (penutur) dalam memilih kata dan menyusun kalimat (Zarqany, 1993). 
Banyak studi yang mengkaji tentang kisah Luqman. Zainal Arifin, misalnya, mengkaji tentang Pendidikan Keluarga di Era Modern dalam Kontek Long Life Education Berdasarkan al-Qur'an Surat Luqman (Arifin, 2017) dan Robitoh Widi Astuti, mengkaji tentang Komunikasi Orang Tua dan Anak Perspektif Kisah dalam al-Qur'an (Astuti, 2011). Akan tetapi, penelitian pertama memfokuskan kajian pada konsep pendidikan yang ditawarkan al-Qur'an melalui kisah Luqman, sedangkan penelitian kedua memfokuskan kajian pada model komunikasi orang tua dengan anaknya dalam keadaan tertentu. Selain kedua penelitian tersebut masih banyak penelitian yang mengkaji kisah Luqman atau surat Luqman, namun kebanyakan memfokuskan kajian pada pendidikan. Oleh karena itu, penelitian ini perlu dilaksanakan mengingat belum adanya penelitian kisah Luqman yang mengkaji dari perspektif gaya bahasa. Luqman melalui gaya bahasanya mampu menguasai dunia si anak dengan menerapkan speech act, thematic structure, dan propositional content, kemudian diakhiri dengan pemberian ruang berfikir anak.

\section{Metode}

Penelitian ini merupakan penelitian sinkronis yang meneliti bahasa dari kurun waktu tertentu. Menurut Mahsun, penelitian sinkronis bersifat deskriptif. Dalam penelitian ini surat Luqman dijadikan sebagai objek material, karena memiliki konsep pendidikan yang ideal menurut alQur'an. Stilistika sebagai objek formal digunakan sebagai alat untuk mendeskripsikan gaya bahasa yang digunakan Luqman dalam mendidik anaknya. Metode simak digunakan untuk mengetahui penggunaan bahasa dalam surat Luqman. Dilanjutkan dengan metode catat untuk mengumpulkan data-data yang hendak diteliti. Adapun metode yang digunakan untuk menganalisis surat Luqman, yaitu metode padan 
intralingual. Mahsun berpendapat bahwa metode padan intralingual digunakan untuk menganalisis bahasa dengan cara menghubungbandingkan unsur-unsur internal bahasa (Mahsun, 2012). Meski objek material utama berupa surat Luqman, namun objek material lain berupa referensi-referensi yang mendukung dalam bentuk buku, artikel, atau pun referensi lain digunakan guna melengkapi pembahasan.

\section{Hasil dan Pembahasan}

\subsection{Fokus Kajian Stilistika}

Stilistika merupakan derivasi dari kata style atau stylus (bahasa latin) yang berarti bulu burung (Qalyubi, 2008). Dalam bahasa Arab dikenal dengan istilah Uslūb, sebagaimana yang dijelaskan az-Zarqani dalam Manahilul Irfan, uslüb adalah cara berbicara yang diambil mutakallim dalam memilih kata dan menyusun kalimat (Zarqany, 1993). Menurut Nyoman, stilistika adalah segala sesuatu yang diungkapkan secara khusus sehingga pesan yang dituju dapat tersampaikan secara maksimal (Ratna, 2009). Meski tokoh pertama tidak secara eksplisit menyebutkan pesan yang disampaikan, namun keduanya sama dalam menganggap stilistika sebagai cara berbicara. Oleh karena itu ranah kajian stilistika menjadi luas, karena menyangkut segala pembicaraan.

Menurut Syukri Muhammad 'Ayyad, sebagaimana dikutip Syihabuddin Qalyubi, ranah kajian stilistika melingkupi semua fenomena bahasa dari fonologi hingga semantik (Qalyubi, 2009). Dengan demikian, kajian stilistika membutuhkan ruang pendeskripsian yang banyak, sehingga mendapatkan kajian yang komprehensif. Namun, bukan termasuk sesuatu yang keliru jika mengkaji bagian dari ranah stilistika. Boleh jadi, pendeskripsian kajian memiliki ruang yang terbatas. 
Dalam keterangan lain, Qalyubi mengutip pendapat Nabil 'Ali Hasanain yang mengatakan bahwa uslüb (stilistika) membahas seluruh kajian balaghah dan kajian linguistik. Lebih lanjut, Qalyubi membaginya menjadi lima ranah kajian, yaitu: al-mustawa al-șauti (fonologi), al-mustawa al-șarfi (morfologi), al-mustawa al-nahwi atau al-tarkibi (sintaksis), al-mustawa al-daläli (semantik), dan al-mustawa al-tașwìri (imageri) (Qalyubi, 2013). Oleh karena keterbatasan ruang publikasi, penelitian ini difokuskan pada ranah kajian al-mustawa al-nahwi atau al-tarkibi dengan alasan, al-mustawa al-nahwi (kalimat) merupakan ranah minimal untuk menyampaikan pesan komunikator kepada komunikannya secara sempurna.

Al-Mustawa al-Nahwi mengkaji tentang pola struktur kalimat, repetisi, baik kata, kalimat maupun kisah, serta pengaruhnya terhadap makna, dan lain-lain. Al-mustawa al-nahwi berbeda dengan ilmu nahwu. Ilmu nahwu membahas tentang i'rab (perubahan harakat pada huruf terakhir suatu kata) atau membahas kedudukan kata dalam kalimat. Adapun al-mustawa al-nahwi membahas rahasia makna dibalik penggunaan i'rab ataupun kedudukan kata (Qalyubi, 2013). Dengan demikian, istilah nahwu memiliki dua konteks, nahwu dalam perspektif linguistik Arab dan nahwu dalam perspektif stilistika (uslūb).

\subsection{Urgensi Bahasa dalam Mendidik Anak}

Dalam KBBI, kata "bahasa" diartikan sebagai sistem lambang bunyi berartikulasi secara arbitrer dan konvensional yang digunakan sebagai alat komunikasi untuk melahirkan pikiran dan perasaan (Bahasa, 1988). Dalam bahasa Arab dikenal dengan istilah lugah yang merupakan bentuk reduksi dari kata lugwatun (masdar) berasal dari lagā (fi'il māḍ̂̀), yalgū (fi'il muḍāri') berarti berbicara (Manzur, n.d.). Ada pula yang mengatakan berasal dari lagiya (fi'il mādù) yalgā (fi'il muḍāri') (Jinni, 1913). Lugah diartikan sebagai 
suara-suara yang diibaratkan (digunakan) setiap kelompok untuk menyampaikan tujuan (Umar, 2008). Dalam bahasa Inggris, bahasa (language) diartikan dengan sistem komunikasi yang digunakan untuk berbicara dan menulis oleh orang-orang pada suatu negara (Oxford: Learner's Pocket Dictionary, 2008).

Ada banyak tokoh yang berkontribusi dalam menjelaskan hakikat bahasa. Kridalaksana mendefinisikan bahasa dengan sistem lambang bunyi yang dipergunakan oleh masyarakat tertentu untuk bekerja sama, berinteraksi, dan menyesuaikan diri (Kridalaksana, 2009). Sobur, sebagaimana dikutip Muzakki, mendefinisikan bahasa dengan kombinasi kata yang diatur secara sistematis, sehingga dapat digunakan suatu masyarakat untuk berkomunikasi (Muzakki, 2007). Saussure, mendefinisikan bahasa dengan perbendaharaan kata dalam pranata sosial yang didasarkan atas konvensi penggunanya (Kridalaksana, 2005).

Dari beberapa definisi bahasa di atas, dapat diambil salah satu kata kunci yang terdapat di dalam masing-masing definisi tersebut, yaitu interaksi, komunikasi, dan pranata sosial. Ketiga kata kunci ini mengarah pada aktivitas bahasa yang digunakan oleh dua atau banyak orang, sebagaimana dijelaskan Abdul Chaer bahwa secara fungsi, bahasa merupakan alat komunikasi manusia (Chaer, 2012).

Pada saat komunikasi berlangsung, hendaknya penutur mengetahui psikologi lawan tuturnya. Penutur harus mempertimbangkan pilihan kata dan kalimat saat berkomunikasi dengan lawan tutur yang sedang sedih, karena pesan yang disampaikan dapat tereduksi maknanya oleh lawan tutur. Beda halnya saat berkomunikasi dengan lawan tutur yang sedang gembira. Penutur dapat mengekspresikan ide dalam bentuk candaan, ejekan, perumpamaan, atau variasi ekspresi lain. 
Dalam psikolinguistik, seorang petutur harus mengetahui tiga aspek penting saat berkomunikasi. Ketiga aspek tersebut yaitu: speech act, thematic structure, dan propositional content. Speech act adalah tindakan seseorang saat berkomunikasi, baik meminta, meyakinkan, berjanji, menyuruh, dan lain-lain. Thematic structure adalah penilaian penutur tentang kondisi mental lawan tutur saat berkomunikasi. Adapun propositional content adalah pertimbangan penutur dalam memilih kata dan merangkai kalimat agar ide yang berada dalam pikiran dapat tersampaikan (Mar'at, 2011).

Ketiga aspek tersebut, juga berguna dalam komunikasi orang tua kepada anaknya. Terlebih, saat orang tua memberikan nasihat, arahan, dan pendidikan kepada anak. Orang tua yang mengiringkan tiga aspek tersebut dalam komunikasi cenderung mendapat respon dari anak, karena ide yang disampaikan menyesuaikan kondisi psikologis anak, sehingga anak siap untuk menerima nasihat, arahan, dan pendidikan. Dengan adanya kesiapan psikologis anak, hakikat pendidikan untuk mengaktualisasikan potensi anak dapat terlaksana (Nata, 2012).

Sebaliknya, orang tua yang mengikutsertakan kondisi psikologisnya saat berkomunikasi dengan anak cenderung kurang mendapat respon, karena ide yang disampaikan bersama dengan psikologis orang tua berbeda dengan kondisi psikologis anak. Kurangnya pengetahuan orang tua terhadap kondisi demikian menjadikan komunikasi gagal. Nasihat, arahan, dan pendidikan yang disampaikan sulit diterima oleh anak. Akibatnya, tujuan pendidikan untuk membentuk perilaku anak tidak terlaksana (Nata, 2012).

\subsection{Gaya Bahasa Luqman dalam Mendidik Anaknya}

1) Gaya Bahasa Deklaratif (Ikhbariyah) 
Kalimat deklaratif adalah ungkapan yang mengandung kebenaran atau kebohongan itu sendiri tanpa memandang orang yang membawa kabar tersebut (mukhbir). Kalimat ini merupakan ungkapan realitas dan peristiwa (Ali, 1995). Kalimat ini dibagi menjadi dua, yaitu kalimat nominal (jumlah ismiyah) dan kalimat verbal (jumlah fi'liyah) (Ali, 1995). Kalimat nominal adalah kalimat yang terdiri dari subjek/ mubtada dan predikat/ khobar, sedangkan kalimat verbal adalah kalimat terdiri atas kata kerja/ fi'il dan pelaku pekerjaan ( $\left.f a^{\prime} i l\right)$ atau pengganti pelaku pekerjaan (na'ibul fa'il).

Penggunaan dua ragam kalimat tersebut banyak tersebar dalam surat Luqman. Keduanya memiliki porsi pengungkapan yang simbang. Melalui keseimbangan ini, dapat dikatakan bahwa Luqman merupakan orang tua yang bijaksana dan dapat dijadikan panutan, karena tindakan yang dilakukan sesuai dengan berita yang disampaikan. Dengan kalimat lain, Luqman melakukan perbuatan sesuai dengan ucapan yang dituturkan. Dalam surat luqman, kalimat nominal terdapat pada ayat: 2, 4, 5, 6, 8, 11, $16,22,23,26,27,28,30,33,34$, sedangkan kalimat verbal terdapat pada ayat $7,10,12,13,14,15,17,18,19,20,21,24,25,29,31,32$.

Ada beberapa makna yang ditimbulkan dari penggunaan kalimat deklaratif (jumlah ikhbariyah), yaitu: menunjukkan kelemahan dan kekhusyuan, menjadikan sesuatu yang besar terlihat kecil, kata kerja sekarang dan akan datang juga dimaknai lampau.

Pertama, makna yang menunjukkan kelemahan dan kekhusyuan terdapat pada ayat 26 yang berbunyi:

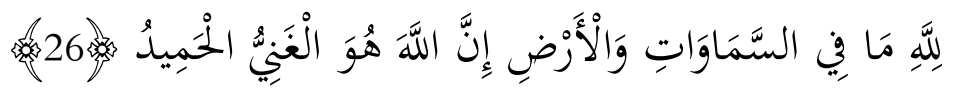

“Kepunyaan Allah-lah apa yang di langit dan yang di bumi. Sesungguhnya Allah lah Yang Maha Kaya lagi Maha Terpuji." 
Pada ayat di atas nuansa yang terbangun adalah betapa lemahnya kekuasaan manusia di hadapan Allah, terlebih ketika memohon sesuatu adalah kekhusyuan yang ada pada hati seorang hamba. Hal ini membuktikan bahwa segala yang diberikan oleh Allah kepada manusia tidak lebih dari sekedar titipan-Nya yang sewaktu-waktu bisa diambil kapan saja.

Kedua, makna menjadikan sesuatu yang besar terlihat kecil terdapat pada ayat 28 yang berbunyi:

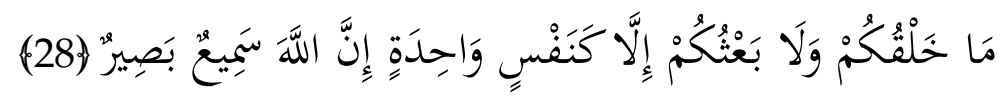

“Tidaklah Allah menciptakan dan membangkitkan kamu (dari dalam kubur) itu melainkan hanyalah seperti (menciptakan dan membangkitkan) satu jiwa saja. Sesungguhnya Allah Maha Mendengar lagi Maha Melihat"

Pada ayat di atas nuansa yang terbangun adalah Allah dapat meringankan sesuatu yang besar dan tidak mungkin bisa dilakukan oleh manusia. Di tangan Allah segala sesuatunya dapat dilakukan dengan mudah. Sebab Dialah yang berkuasa untuk menciptakan dan membangkitkan manusia. Meskipun dalam pandangan manusia hal itu bisa dianggap sesuatu yang besar namun di hadapan Allah, hal tersebut sangatlah kecil.

Ketiga, kata kerja sekarang dan akan datang juga dimaknai lampau terdapat pada ayat 12 yang berbunyi:

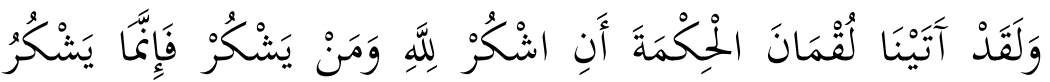

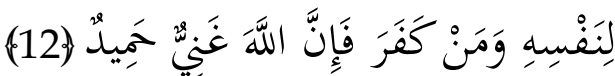

“Dan sesungguhnya telah Kami berikan hikmat kepada Luqman, yaitu: Bersyukurlah kepada Allah. Dan barangsiapa yang bersyukur (kepada Allah), maka sesungguhnya ia bersyukur untuk dirinya sendiri; 
dan barangsiapa yang tidak bersyukur, maka sesungguhnya Allah Maha Kaya lagi Maha Terpuji."

Penggunaan kata kerja yang menunjukkan makna sekarang dan lampau (fi'il mudhari) di atas juga menunjukkan makna lampau, karena kata kerja tersebut menceritakan kisah Luqman yang pada saat itu sedang menasehati putra-putranya agar selalu tetap bersyukur kepada Allah. Hal ini dimaksudkan bahwa bersyukur tidak memandang waktu baik karunia yang didapatkan sekarang, akan datang, maupun yang sudah lalu.

2) Gaya Bahasa Interogatif (Istifhāmiyyah)

Dalam khazanah sastra Arab, kalimat introgatif atau pertanyaan dikenal dengan istilah al-jumlah al-istifhāmiyyah atau juga lazim dikenal dengan sebutan istifham. Istifham adalah kalimat yang ditujukan untuk meminta informasi tentang sesuatu yang belum diketahui oleh penuturnya. Pada umumnya, kalimat pertanyaan didahului dengan salah satu kata seperti: al-hamzah, hal, mā, kaifa, man, limā, dan ayyu (Hasyimi, 1994).

Meski kalimat introgatif digunakan untuk meminta informasi, namun Luqman menggunakannya untuk penggunaan lain dalam mendidik anaknya. Dalam mendidik anaknya luqman menggunakan kalimat introgatif untuk menunjukkan peringatan dan ketakjuban. Pertama, kalimat introgatif yang menunjukkan peringatan terdapat pada ayat 20 yang berbunyi:

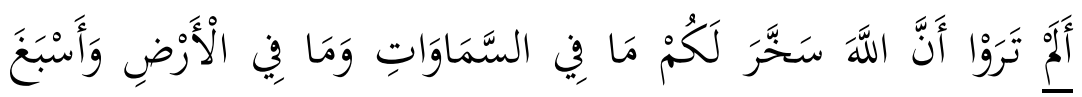

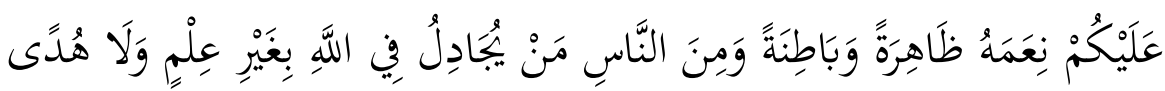

$$
\begin{aligned}
& \text { وَلَال كِتَابِ مُنيٍٍِ (20) }
\end{aligned}
$$


“Tidakkah kamu perhatikan sesungguhnya Allah telah menundukkan untuk (kepentingan)mu apa yang di langit dan apa yang di bumi dan menyempurnakan untukmu nikmat-Nya lahir dan batin. Dan di antara manusia ada yang membantah tentang (keesaan) Allah tanpa ilmu pengetahuan atau petunjuk dan tanpa Kitab yang memberi penerangan."

Penggunaan kalimat introgatif pada ayat di atas tidak membutuhkan jawaban. Kalimat introgatif tersebut hendak memberi pengertian kepada orang-orang yang lupa atas karunia Allah Swt. Kalimat tersebut digunakan untuk mengingatkan mereka agar bersedia kembali kepada Allah Swt yang telah memberikan nikmat kepada hamba-hamba-Nya.

Kedua, kalimat introgatif yang menunjukkan ketakjuban terdapat pada ayat 29 dan 31, yang berbunyi:

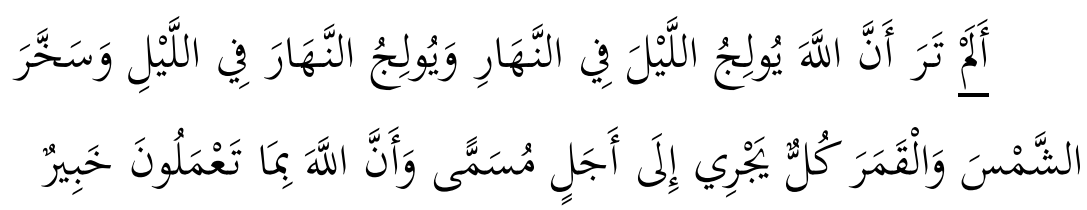

“Tidakkah kamu memperhatikan, bahwa sesungguhnya Allah memasukkan malam ke dalam siang dan memasukkan siang ke dalam malam dan Dia tundukkan matahari dan bulan masing-masing berjalan sampai kepada waktu yang ditentukan, dan sesungguhnya Allah Maha Mengetahui apa yang kamu kerjakan."

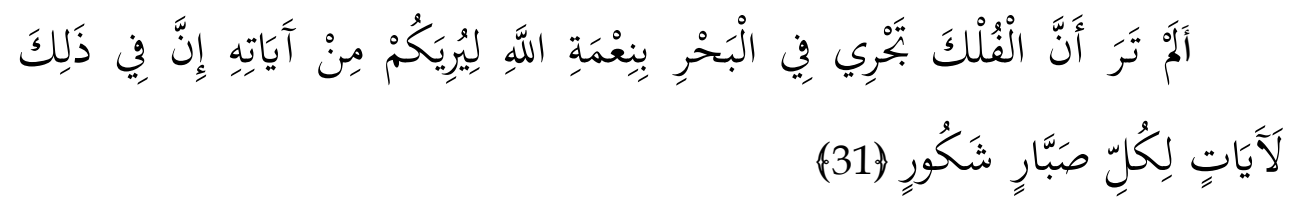

“Tidakkah kamu memperhatikan bahwa sesungguhnya kapal itu berlayar di laut dengan nikmat Allah, supaya diperlihatkan-Nya kepadamu sebahagian dari tanda-tanda (kekuasaan)-Nya. Sesungguhnya 
pada yang demikian itu benar-benar terdapat tanda-tanda bagi semua orang yang sangat sabar lagi banyak bersyukur"

Penggunaan kalimat introgatif pada dua ayat di atas tidak membutuhkan jawaban. Kalimat introgatif tersebut hendak memberikan gambaran ketakjuban, bahwa tidak ada yang bisa menandingi ciptaan Allah Swt. Mematahkan kesombongan orang-orang yang tidak berada di jalan yang ridhoi-Nya. Mengingatkan mereka yang lupa bersyukur atas kenikmatan Allah Swt.

3) Gaya Bahasa Pengedepanan dan Pengakhiran (at-taqdìm wa at-ta'khìr)

Secara istilah, at-taqdìm wa at-ta'khìr adalah suatu proses pendahuluan posisi dari sesuatu yang kemudian mengakhirkan yang lain. Menurut Jurjani, at-taqdìm wa at-ta'khìr terbagi menjadi dua yaitu: mendahulukan atau mengakhirkan posisi tanpa merubah hukum, seperti mendahulukan khabar daripada mubtada dan mendahulukan atau mengakhirkan posisi disertai dengan perubahan hukumnya (Jurjani, 1992).

Gaya pengedepanan dan pengakhiran telah keluar dari teori linguistik Arab yang standar. Keluarnya gaya pengedepanan dan pengakhiran dari teori linguistik Arab standar bukan termasuk kesalahan. Penutur, dengan variasi gaya tersebut ingin menunjukkan kepada lawan tutur adanya sesuatu ide yang mengalir di dalamnya, karena dimungkinkan ide tersebut tidak dapat tersampaikan jika penutur menggunakan gaya bahasa standar. Oleh karena itu, gaya pengedepanan dan pengakhiran memiliki tujuan tertentu, diantaranya: tasywì (kejutan atau ketegangan), ifädatu al-ikhtișāṣ (pengkhususan).

Gaya pengedepanan dan pengakhiran yang memiliki tujuan tasywiq, terdapat pada ayat 6 , yang berbunyi: 


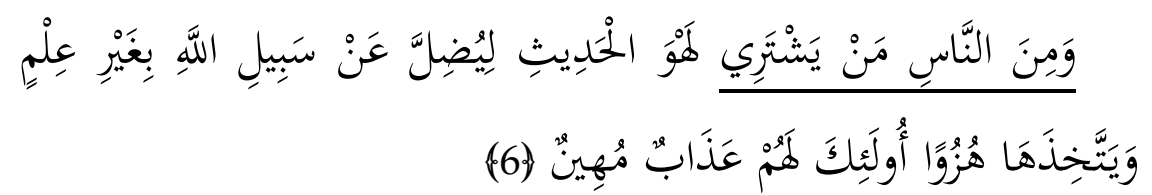

“Dan di antara manusia (ada) orang yang mempergunakan perkataan yang tidak berguna untuk menyesatkan (manusia) dari jalan Allah tanpa pengetahuan dan menjadikan jalan Allah itu olok-olokan. Mereka itu akan memperoleh azab yang menghinakan."

Ayat di atas merupakan jumlah ismiyah dengan susunan khobar muqodam (wa mina al-nāsi) dan mubtada muakhor (man yasytarì). Adapun maksud yang mungkin ingin dikehendaki si punutur adalah untuk tasywiq (kejutan, ketegangan). Sebagaimana dalam firman-Nya, Allah langsung memberi kejutan dengan membagi manusia di antaranya mereka yang menggunakan ucapannya untuk menyesatkan manusia dari Allah tanpa ilmu pengetahuan.

Gaya pengedepanan dan pengakhiran yang memiliki tujuan ifädatu al-ikhtișās (pengkhususan) (Misry, 2009) terdapat pada ayat 14, yang berbunyi:

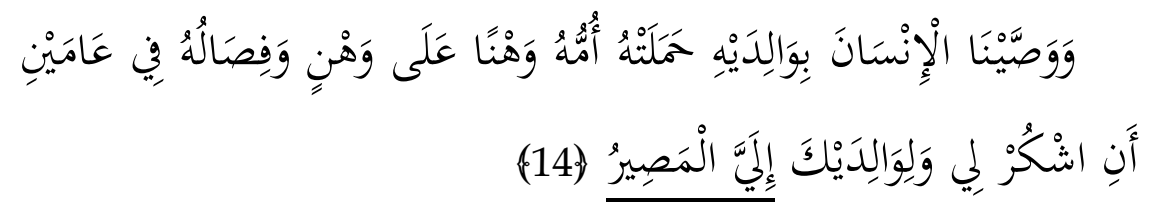

"Dan Kami perintahkan kepada manusia (berbuat baik) kepada dua orang ibu-bapanya; ibunya telah mengandungnya dalam keadaan lemah yang bertambah-tambah, dan menyapihnya dalam dua tahun. Bersyukurlah kepadaKu dan kepada dua orang ibu bapakmu, hanya kepada-Kulah kembalimu."

Pengedepanan lafaz ilayya dibandingkan dengan al-masir memberikan efek bahwa segala bentuk nikmat yang diberikan oleh orang 
tua, pada dasarnya bersumber dari Allah Swt. Maka sudah sepantasnya pengedepanan lafaz tersebut sebagai bentuk pengkhususan.

4) Gaya Bahasa Pemalingan (iltifāt)

Secara bahasa, al-iltifat berarti berpindah atau menoleh (Manzur, n.d.). Sementara menurut istilah sendiri arti al-iltifat hampir tidak ada perbedaan dengan artinya menurut bahasa, yaitu perpindahan dari satu bentuk ke bentuk yang lain (Dhaif, 2011). Perpindahan bentuk yang dimaksud dalam definisi ini, pada awalnya hanya sebatas perpindahan antara damir sebagaimana yang disepakati oleh ulama balaghah klasik, namun pada perkembangannya ia tidak hanya terbatas pada perpindahan damir saja, malainkan pada perpindahan antar-kata, bahkan kalimat (Sulaiman, 2004).

Menurut Abu Ubaidah, semua perpindahan yang ada dalam ucapan termasuk iltifat. Misalnya, perpindahan dari makna satu ke makna lain, perpindahan kalimat satu ke kalimat lain (jumlah fi'liyyah ke jumlah ismiyyah), perpindahan penggunaan bentuk kata (dari madhi ke mudhari atau sebaliknya), perpindahan bentuk mufrad ke jamak, dan perpindahan bentuk damir satu ke bentuk damir lain (Noor \& Bahri, 2020).

Dalam surah Luqman, terdapat beberapa iltifat sebagaimana disebutkan di atas, yaitu: perpindahan dari damir huwa (kata ganti laki-laki satu) ke damir nahnu (kata ganti kami atau kita), perpindahan dari fi'il mudhari (kata kerja yang menunjukkan waktu sekarang atau waktu akan datang) ke fi'il madhi (kata kerja yang menunjukkan waktu lampau), dan perpindahan dari jumlah ismiyyah ke jumlah fi'liyyah.

Pertama, perpindahan dari damir huwa ke damir nahnu, sebagaimana terdapat pada ayat 10, yang berbunyi: 


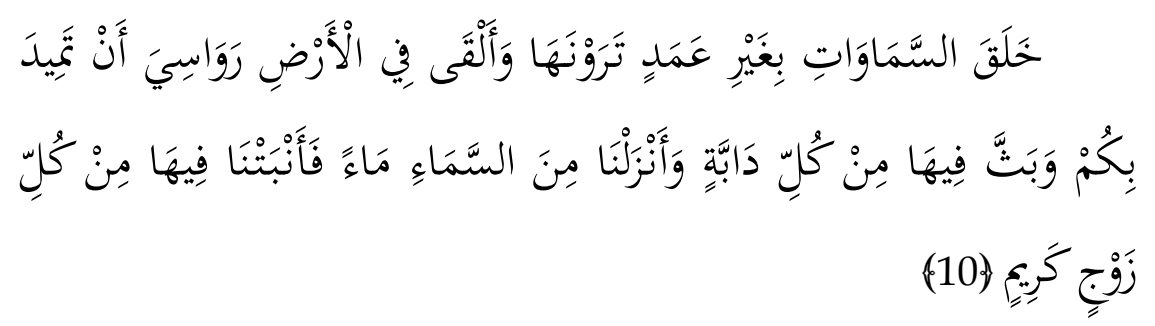

“Dia menciptakan langit tanpa tiang yang kamu melihatnya dan Dia meletakkan gunung-gunung (di permukaan) bumi supaya bumi itu tidak menggoyangkan kamu; dan memperkembang biakkan padanya segala macam jenis binatang. Dan Kami turunkan air hujan dari langit, lalu Kami tumbuhkan padanya segala macam tumbuh-tumbuhan yang baik."

Bentuk iltifat di sini adalah perpindahan dari damir huwa (khalaqa/ alqay/ bassa) kepada dami mutakallim ma'al ghoir nahnu (anzalna/ anbatna). Hal ini mengandung pengertian bahwa penciptaan langit, mengembangbiakan hewan dan menancapkan gunung adalah kekuasaan yang dimiliki Allah sedangkan agar tumbuhan itu bisa tumbuh memang harus ada campur tangan manusia salah satunya dengan menyiram tumbuhan tersebut baik dengan air hujan ataupun air sungai.

Kedua, perpindahan dari fi'il mudhari ke fi'il madhi, sebagaimana terdapat pada ayat 29 , yang berbunyi:

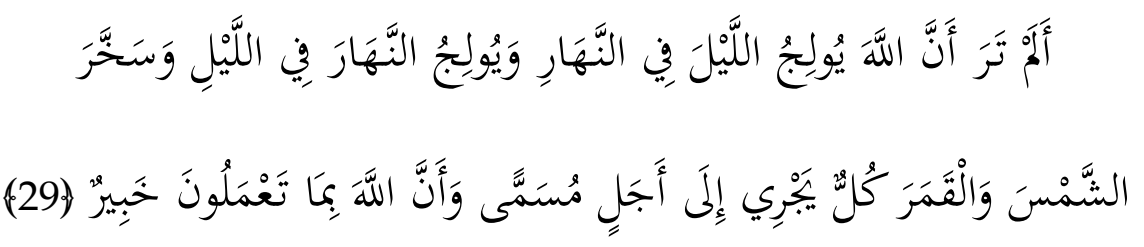

“Tidakkah kamu memperhatikan, bahwa sesungguhnya Allah memasukkan malam ke dalam siang dan memasukkan siang ke dalam malam dan Dia tundukkan matahari dan bulan masing-masing berjalan sampai kepada waktu yang ditentukan, dan sesungguhnya Allah Maha Mengetahui apa yang kamu kerjakan" 
Bentuk iltifat ini adalah fi'il mudhari (yüliju) kepada fi'il madhi (sakhkhara). Pemalingan ini mengandung pengertian bahwa pergantian siang dan malam atau sebaliknya merupakan proses yang selalu akan terjadi, akan tetapi penundukan matahari dan bulan sudah sejak lama terjadi. Oleh karena itu, tidak perlu diungkapkan secara terus menerus.

Ketiga, perpindahan dari jumlah ismiyyah ke jumlah fi'liyyah, sebagaimana terdapat pada ayat 11, yang berbunyi:

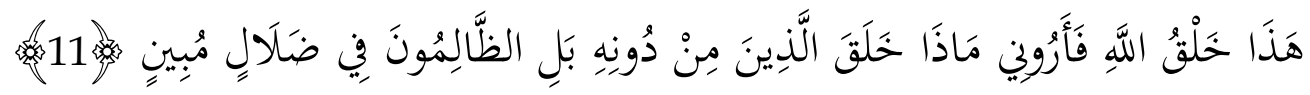

"Inilah ciptaan Allah, maka perlihatkanlah olehmu kepadaku apa yang telah diciptakan oleh sembahan-sembahan $(\mathrm{mu})$ selain Allah. Sebenarnya orang- orang yang zalim itu berada di dalam kesesatan yang nyata."

Dalam ayat ini terjadi pemalingan dari jumlah ismiyah (khalqu) kepada jumlah fi'liyah (khalaqa). Pemalingan ini mengandung pengertian bahwa orang-orang yang berbuat dhalim akan selalu membuat ciptaan-ciptaan tuhan untuk mereka sembah sendiri sampai saat ini, maka penggunaan jumlah fi'liyah pada kata khalaqa sangatlah tepat.

\section{Kesimpulan}

Bahasa merupakan sarana komunikasi paling penting di antara sarana komunikasi lainnya, khususnya dalam mendidik anak. Orang tua perlu mempertimbangkan pilihan kata dan penyusunan kalimat saat memberikan nasihat. Selain itu, orang tua juga perlu menerapkan speech act, thematic structure, dan propositional content saat berkomunikasi dengan anak, sebagaimana dilakukan Luqman kepada anaknya. Speech act diterapkan Luqman saat memberikan pengetahuan dalam bentuk deklaratif. Hal ini dilakukan untuk menjaga mental si anak (thematic 
structure) agar tidak merasa didiskriditkan atas perilakunya, sebagaimana makna yang menunjukkan kelemahan diterapkan pada sesuatu yang lain. Selain itu, mental si anak juga akan bertambah kuat saat Luqman menjadikan sesuatu yang besar terlihat kecil. Hal ini berguna dalam menjaga mental agar tidak jatuh saat menghadapai kesulitan. Speec act juga diterapkan Luqman saat meminta informasi kepada anaknya, meskipun informasi tersebut tidak langsung diutarakan anak setelah mendengar kalimat interogatif. Luqman dengan sengaja membiarkan jawaban mengambang dengan menunjukkan makna peringatan dan ketakjuban agar si anak tidak merasa diinterogasi, karena bisa mempengaruhi kondisi mental (thematic structure). Setelah mengetahui kondisi mental si anak, propositional content secara eksplisit mulai ditampakkan dalam kalimat taqdim wa ta'khir. Luqman secara perlahan memberikan kejutan dan pengkhususan melalui pilihan kata dan penyusunan kalimatnya. Setelah menerapkan ketiganya, Luqman memberikan ruang berfikir kepada anaknya atas nasihat yang diberikan kepadanya menggunakan iltifat, baik dari damir huwa ke damir nahnu, dari fi'il mudhari ke fi'il madhi, maupun dari jumlah ismiyyah ke jumlah fi'liyyah.

\section{Referensi}

Ali, F. H. T. al-. (1995). Al-Balagah Al-Muyassarah. Yordania: Maktabah Dar as-Saqofah.

Arifin, Z. (2017). Pendidikan Keluarga Di Era Modern Dalam Kontek Long Life Education Berdasarkan Al-Qur'an Surat Luqman. Wahana Karya Ilmiah Pendidikan, 1(1), 72-87.

Astuti, R. W. (2011). Komunikasi Orang Tuan dan Anak Perspektif Kisah dalam al-Qur'an. UIN Sunan Kalijaga.

Bahasa, P. P. dan P. (1988). Kamus Besar Bahasa Indonesia. Jakarta: Balai 
Pustaka.

Chaer, A. (2012). Linguistik Umum. Jakarta: Rineka Cipta.

Dhaif, S. (2011). Al-Mu'jam Al Wasit. Mesir: Maktabah Shuuq AdDauliyyah.

Hasyimi, A. A.-. (1994). Jawwāhir Al-Balāgah. Beirut: Dar al-Fikr.

Hendarman. (2019). Pendidikan Karakter Era Milenial. Bandung: Remaja Rosdakarya.

Jinni, A. al-F. 'Usman bin. (1913). Al-Khasais. Mesir: Daar al-Kutub al-Misri. Jurjani, A. al-Q. al-J. (1992). Dalail Al-I'jaz. Jeddah: Dar al-Madani.

Kridalaksana, H. (2005). Mongin-Ferdinand de Saussure: Peletak Dasar Strukturalisme dan Linguistik Modern. Jakarta: Yayasan Obor Indonesia. Kridalaksana, H. (2009). Kamus Linguistik. Jakarta: Gramedia.

Mahsun. (2012). Metode Penelitian Bahasa: Tahapan Strategi, Metode, dan Tekniknya. Jakarta: Rajawali Pers.

Manzur, M. bin M. ibn. (n.d.). Lisan, Al 'Arab. Beirut: Dar Sadr.

Mar'at, S. (2011). Psikolinguistik: Suatu Pengantar. Bandung: Refika Aditama.

Misry, M. M. al. (2009). Dalalatu al-Taqdim wa al-Ta'khir Fi Al Quran Al Karim; Dirasah Tahliliyah. Kairo: Maktabah Wahibah.

Muzakki, A. (2007). Kontribusi Semiotika dalam Memahami Bahasa Agama. Malang: UIN-Malang Press.

Nata, A. (2012). Pemikiran Pendidikan Islam dan Barat. Jakarta: Rajawali Pers.

Noor, D. D., \& Bahri, R. B. H. (2020). Uslub Al-Iltifat Fi Dirasat Ulama AlBalagah Al-Qadim Wal Hadits. LiNGUA: Jurnal Ilmu Bahasa Dan Sastra, 14(2), 235. https:/ / doi.org/10.18860/ling.v14i2.7292

Oxford: Learner's Pocket Dictionary. (2008). Oxford University Press.

Qalyubi, S. (2008). Stilistika dalam Orientasi Studi Al-Qur'an. Sleman: Belukar. 
Chotibul Umam, Muhammad Alghiffary

Qalyubi, S. (2009). Stilistika Al-Qur'an: Makna di Balik Kisah Ibrahim. Yogyakarta: LKiS.

Qalyubi, S. (2013). Ilm Al-Uslūb: Stilistika Bahasa dan Sastra Arab. Yogyakarta: Karya Media.

Ratna, N. K. (2009). Stilistika: Kajian Puitika Bahasa, Sastra, dan Budaya. Yogyakarta: Pustaka Pelajar.

Sulaiman, F. A. (2004). Al-Uslubiyah: Madkhal Nazariyah Wa Dirasah Tatbiqiyah. Kairo: Maktabah al Adab.

Umar, A. M. (2008). Mu'jam Al-Lughah Al-'Arabiyah Al-Mu'āṣirah. Mesir: ‘Ālam Al-Kutub.

Zarqany, M. A. al-'Azdim al-. (1993). Manāhil al-'Irfān fi 'Ulūm al-Qur'an. Mesir: Dar al-Ihya'. 
Chotibul Umam, Muhammad Alghiffary

\begin{tabular}{|c|}
\hline $\begin{array}{l}\text { 'Halaman Ini Sengaja Dikosongkan' } \\
\text { This Page Is Intentionally Left Blank }\end{array}$ \\
\hline تركت هذه الصفحة فارغة عمدا \\
\hline
\end{tabular}

